\title{
Pemanfaatan Dana Bank Rakyat Indonesia (BRI) sebagai Sumber Pembiayaan Nelayan Gorontalo
}

\author{
Tiansi Febriani Idrus ${ }^{1)}$, Melizubaida Mahmud ${ }^{2)}$ \\ 1)Mahasiswa Jurusan Pendidikan Ekonomi, Universitas Negeri Gorontalo \\ 2)Dosen Jurusan Pendidikan Ekonomi, Universitas Negeri Gorontalo \\ tiansifebrianiidrus@yahoo.com
}

\begin{abstract}
The research aims to find out the effetiviness of utilization of fund form BRI as fishermen's financing source in Tanjung Kramat village,to find out supporting factors as well as inhibiting factors at people in Tanjung Kramat Village to achieve credit fund form Bank Rakyat Indonesia. The research method is a qualitative approach. The technique of data collection, interview and documentation. The findings show that the effectiviness ratio level is more than $100 \%$ and it means fund form Bank Rakyat Indonesia is very helpful for fishermen in Tanjung Kramat Village to increase the income. In addition, there are also two factors which support people in selecting fund form BRI as financing source namely internal and external factors. Also, there are also inhibiting factors namely credit instalment, credit value, collateral value, credit term, credit procedure/terms, credit provider allocation, and others.
\end{abstract}

Keywords: Utilization of Fund form Bank Rakyat Indonesia (BRI); Fishermen Financing Source

\section{Pendahuluan}

Masyarakat nelayan tentu membutuhkan dana untuk melakukan kegiatannya dengan memanfaatkan bank untuk memberikan pembiayaan ataupun pendanaan, oleh karena itu hal in menjadi peluang untuk bank dan untuk membantu masyarakat nelayan dalam hal pendanaan agar dalam aktivitas nelayannya berjalan lancar. Hal ini akan menjadi suatu kerjasama yang saling menguntungkan antara masyarakat nelayan dengan bank dan lembaga keuangan lainnya karena samasama saling membutuhkan.

Kelurahan Tanjung Kramat Kecamatan Hulonthalangi Kota Gorontalo merupakan salah satu 
darrah yang potensial di Kecamatan Hulonthalangi. Pada umumnya masyarakat Tanjung Kramat bermata pencaharian sebagai nelayan dan bekerja sebagai nelayan merupakan salah satu pekerjaan yang diandalkan oleh masyarakat Tanjung Kramat karena daerah yang potensial menghasilkan ikan. Ada 286 penduduk di Kelurahan Tanjung Kramat yang bekerja sebagai nelayan. Hal itu pula dijumpai penulis dilapangan bahwa masih banyak nelayan tradisional tergolong miskin. Sebagian besar dari anak-anak nelayan tidak menamatkan pendidikan dan para nelayan pun memiliki tingkat pendidikan yang sangat rendah, hal itu disebabkan oleh kurangnya biaya, akses sekolah yang jauh dari tempat tinggal, serta kondisi sosial yang tidak memungkingkan, tetapi dilain hal mereka merupakan pewaris bangsa.

Berdasarkan latar belakang peneliti tertarik untuk melakukan penelitian yang berjudul “Efektivitas Pemanfaatan Dana Kredit di Bank BRI Sebagai Sumber Pembiayaan Nelayan Di Kelurahan Tanjung Kramat Kecamatan Hulonthalangi Kota Gorontalo"

\section{Kajian Pustaka \\ Pengertian Efektivitas}

Menurut Kamus Besar

Bahasa Indonesia, kata efektif mempunyai arti efek, pengaruh, akibat atau dapat membawa hasil. Jadi, efektivitas adalah keaktifan, daya guna, adanya kesesuaian dalam suatu kegiatan orang yang melaksanakan tugas dengan sasaran yang dituju. Efektivitas pada dasarnya menunjukkan pada taraf tercapainya hasil, sering atau senantiasa dikaitkan dengan pengertian efisien, meskipun sebenarnya ada perbedaan diantara keduanya. Efektivitas menekankan pada hasil yang dicapai, sedangkan efisiensi lebih melihat pada bagaiman cara mencapai hasil yang dicapai itu dengan membandingkan antara input dan outputnya (Siagaan, 2001: 24).

\section{Sejarah Bank Rakyat Indonesia}

Bank Rakyat Indonesia (BRI) adalah salah satu bank milik pemerintah yang terbesar di Indonesia. Pada awalnya Bank Rakyat Indonesia (BRI) didirikan di Purwokerto, Jawa Tengah oleh Raden Bei Aria Wirjaatmadja dengan nama De Poerwokertosche Hulp en Spaarbank der Inlandsche Hoofden atau "Bank Bantuan dan Simpanan Milik Kaum Priyayi 
Purwokerto", suatu lembaga keuangan yang melayani orangorang berkebangsaan Indonesia (pribumi). Lembaga tersebut berdiri tanggal 16 Desember 1895, yang kemudian dijadikan sebagai hari kelahiran BRI.

\section{Visi Misi Bank Rakyat Indonesia}

\section{Visi BRI}

$\begin{array}{ccr}\text { Menjadi } & \text { bank } & \text { komersial } \\ \text { terkemuka } & \text { yang } & \text { selalu }\end{array}$
mengutamakan kepuasan nasabah.

2. Misi BRI

1) Melakukan kegiatan perbankan yang terbaik dengan mengutamakan pelayanan kepada usaha mikro, kecil dan menengah untuk menunjang peningkatan ekonomi masyarakat.

2) Memberikan pelayanan prima kepada nasabah melalui jaringan kerja yang tersebar luas dan didukung oleh sumber daya manusia yang profesional dan teknologi informasi yang handal dengan melaksanakan manajemen risiko serta praktek Good Corporate Governance (GCG) yang sangat baik.

3) Memberikan keuntungan dan manfaat yang optimal kepada pihak-pihak yang berkepentingan (stakeholders).
Prinsip-Prinsip Bank Rakyat Indonesia

Berikut ini adalah prinsipprinsip Good Corporate Governance yang diterapkan oleh BRI:

1) Transparansi

Keterbukaan dalam melaksanakan proses pengambilan keputusan dan keterbukaan mengemukakan informasi materiil dan relevan mengenai perusahaan.

2) Akuntabilitas

Kejelasan fungsi pelaksanaan dan pertanggungjawaban sehingga pengelolaan perusahaan terlaksana secara efektif.

3) Pertanggungjawaban

Kesesuaian di dalam pengelolaan perusahaan terhadap peraturan perundang- undangan yang berlaku dan prinsip-prinsip korporasi yang sehat.

4) Kemandirian

Suatu keadaan di mana perusahaan dikelola secara profesional tanpa benturan kepentingan dan pengaruh atau tekanan dari pihak manapun yang tidak sesuai dengan peraturan perundang-undangan yang berlaku dan prinsip-prinsip korporasi yang sehat.

5) Kewajaran

Keadilan dan kesetaraan di dalam memenuhi hak-hak 


$\begin{array}{lcr}\begin{array}{l}\text { stakeholders } \\ \text { berdasarkan }\end{array} & \begin{array}{c}\text { yang } \\ \text { perjanjian }\end{array} & \text { timbul } \\ \text { peraturan } & \text { perundang-undangan } \\ \text { yang berlaku. NOKEP: } & \text { S.44- } \\ \text { DIR/9/1983 Tanggal } 1 & \text { Oktober } \\ 1983 . & & \end{array}$

\section{Metode Penelitian}

\section{Desain Penelitian}

Desain penelitian yang digunakan adalah desain penelitian fenomenologis menggunakan pendekatan kualitatif. Penelitian fenomenologis merupakan salah satu jenis penelitian kualitatif, dimana penelti melakukan pengumpulan data dengan observasi partisipan untuk mengetahui fenomena esensial partisipan dalam pengalaman hidupnya.

$$
\text { Pendekatan kualitatif }
$$

bertujuan memahami suatu fenomena dalam konteks sosial secara alamiah dengan mengedepankan proses interaksi komunikasi yang mendalam antara peneliti dengan fenomena yang diteliti. Dalam penelitian ini, peneliti telah melakukan interaksi komunikasi secara dekat dengan informan dan data yang akurat.

\section{Informan Penelitian}

Informan merupakan salah satu hal terpenting sebagai pendukung dalam memenuhi hakhak memperoleh data yang akurat. Oleh karena itu, peneliti harus bisa menentukan mana yang bisa dijadikan informan demi mendukung penelitiannya tersebut. Adapun dalam penelitian ini, yang menjadi informan penelitian sebanyak 9 orang yang terdiri dari:

1. Informan kunci yaitu Pihak Bank BRI (1 orang)

2. Informan pendukung yaitu masyarakat nelayan Kelurahan Tanjung Kramat. (10 orang).

\section{Teknik Pengumpulan Data}

Menurut Sugiyono (2017:104) mengemukakan bahwa teknik pengumpulan data merupakan data yang paling strategis dalam penelitian, karena tujuan utama dari penelitian adalah mendapatkan data. Tanpa mengetahui teknik pengumpulan data maka peneliti tidak akan mendapatkan data melalui standar data yang ditetapkan. Dalam penelitian kualitatif, pengumpulan data dilakukan pada natural setting (kondisi yang alamiah), sumber data primer, dan teknik pengumpulan data lebih banyak pada observasi, wawancara, dan dokumentasi.

Untuk mendapatkan data yang akurat dalam penelitian ini, 
maka peneliti menggunakan teknik pengumpulan data sebagai berikut:

1. Observasi

Nasution, 1988 (Dalam Sugiyono, 2017:106) menyatakan bahwa observasi adalah dasar dari semua ilmu pengetahuan. Para ilmuwan hanya dapat bekerja berdasarkan data, yaitu fakta mengenai dunia kenyataan yang diperoleh melalui observasi. Untuk itu, dalam penelitian ini peneliti melakukan observasi awal bagaimana pendapatan masyarakat nelayan di Kelurahan Tanjung Kramat di tempat penelitian dilakukan.

2. Wawancara

Wawancara merupakan salah satu teknik yang sangat diperlukan dalam memperoleh data dari informan yang akurat dalam penelitian kualitatif. Dimana dalam hal ini, peneliti bertugas sebagai pemberi pertanyaan dan informan merupakan pemberi informasi. Susan Stainback: 1988 (Dalam Sugiyono, 2017: 114) menyatakan bahwa dengan wawancara, maka peneliti akan mengetahui hal-hal yang lebih mendalam tentang partisipan dalam menginterpretasikan situasi dan fenomena yang terjadi, dimana hal ini tidak bisa ditemukan melalui observasi.

Adapun alat-alat yang bisa digunakan sebagai pendukung dalam wawancara yaitu buku catatan yang berfungsi mencatat hal-hal penting, format wawancara yang telah dirancang oleh peneliti, kamera sebagai dokumentasi dan bukti outentik bahwa peneliti telah melakukan penelitian, tape recorder sebagai alat untuk merekam hasil wawancara yang diberikan oleh informan.

\section{Dokumentasi}

Penelitian ini menggunakan metode dokumentasi untuk mengumpulkan dan menganalisis data baik dalam bentuk catatancatatan maupun gambar/foto

\section{Triangulasi}

Teknik pengumpulan data triangulasi diartikan sebagai teknik pengumpulan data yang bersifat menggabungkan dari berbagai teknik pengumpulan data dan sumber data yang telah ada. Bila peneliti melakukan pengumpulan data dengan triangulasi, maka sebenarnya peneliti mengumpulkan data yang sekaligus menguji kredibilitas data, yaitu mengecek kredibilitas data dengan berbagai teknik pengumpulan data dan berbagai sumber data (Sugiyono, 
2017:125). Dimana dalam hal ini, peneliti menggunakan triangulasi teknik, menggunakan teknik pengumpulan data yang berbedabeda, yakni observasi partisipatif, wawancara mendalam, dan dokumentasi untuk mendapatkan data dari sumber yang sama yaitu kepada masyarakat nelayan. Sedangkan triangulasi sumber yaitu mendapatkan data dari sumber yang berbeda-beda dengan teknik yang sama, yakni masyarakat nelayan sebagai peminjam dana dan pihak bank sebagai pemberi pinjaman.

Teknik Analisis Data

Analisis data adalah proses mencari dan menyusun secara sistematis data yang diperoleh dari hasil wawancara, catatan lapangan, dan bahan-bahan lain sehingga dapat mudah dipahami, dan temuannya dapat diinformasikan kepada orang lain. Analisis data dilakukan dengan mengorganisasikan data, menjabarkan ke dalam unit-unit, melakukan sintesa, menyusun ke dalam pola, memilih mana yang penting dan yang akan dipelajari, dan membuat kesimpulan yang dapat diceritakan kepada orang lain, Bogdan (Dalam Sugiyono 2017:130).

\section{Pembahasan}

\section{Kriteria Efektivitas}

Suatu kegiatan atau aktivitas dapat dikatakan efektif bila memenuhi beberapa kriteria tertentu. Efektivitas sangat berhubungan dengan terlaksananya semua tugas pokok, tercapainya tujuan, ketepatan waktu, serta adanya usaha atau partisipasi aktif dari pelaksana tugas tersebut. Secara umum, beberapa tolak ukur atau kriteria efektivitas adalah sebagai berikut:

1. Efektivitas keseluruhan,

2. Produktivitas,

3. Efisiensi,

4. Laba,

5. Pertumbuhan,

6. Stabilitas,

7. Semangat kerja,

8. Kepuasan kerja,

9. Penerimaan tujuan organisasi

10. Keterpaduan,

11. Keluwesan adaptasi,

\section{Produk dan Layanan BRI}

Berikut ini adalah produk produk yang diberikan oleh BRI :
a. Produk Simpanan Bank BRI (Bank Rakyat Indonesia)
b. Tabungan BRI.
c. Deposito BRI
d. Giro BRIBank 

e. Fasilitas Kredit/Pinjaman Bank BRI (Bank Rakyat Indonesia)
f. Pinjaman Mikro BRI
g. Pinjaman Ritel BRI

\section{Sejarah Tanjung Kramat}

Menurut sejarah orang tua bahwa pada tahun 1870 wilayah ini masih hutan belukar dan belum ada orang yang dapat menempati pantai ini. Kemudian oleh karena perkembangan dan perubahan zaman, maka wilayah ini dapat ditempati oleh beberapa masyarakat yang kesemuanya adalah pendatang. Untuk mengetahui siapa mereka, mungkin sulit untuk ditemukan. Tetapi kita dapat yakinkan, tinggal marga yang masih ada. Diantaranya marga Harmain, Ismail, Kama, Koyo, Gani, Usman, Panti, ibrahin dan Halada. Kemudian pada tahun 1908 datanglah orang-orang Mindanau bahasa Gorontalo Mangginano, dengan tujuan mereka ingin menguasai hasil bumi dan daerah Gorontalo.

$\begin{array}{lr}\text { a. Letak geografis } & \text { Kelurahan } \\ \text { Tanjung Kramat } & \\ \text { Wilayah ini } & \text { berbatasan } \\ \text { dengan beberapa } & \text { daerah } \\ \text { disekitarnya yakni: } & \end{array}$
1. Sebelah Utara berbatasan dengan Kelurahan Pohe

2. Sebelah Timur berbatasan dengan Laut

3. Sebelah Selatan berbatasan dengan Laut

4. Sebelah Barat berbatasan dengan Desa Bongo Kabupaten Gorontalo.

b. Mata pencaharian

Saat ini pada umumnya mata pencaharian masyarakat pesisir yang ada di Keluraha Tanjung Kramat adalah sebagai Nelayan. Hal ini karena wilayahnya terletak pada pesisir pantai. Selain itu masih ada juga mata pencaharian lain yang sesuai dengan profesi individu masyarakat Tanjung Kramat seperti Pegawai Negeri Sipil, Petani, Pedagang, dan jasa lainnya.

\section{Gambaran umum instrumen}

Secara umum, gamabaran umum instrument dalam penelitian ini adalah nasabah yang meminjam di Bank Rakyat Indonesia. Nelayan atau nasabah berasal dari Kelurahan Tanjung Kramat. Jumlah Nelayan di Kelurahan Tanjung Kramat sekitar 321 orang. Sementara nelayan yang memanfaatkan dana Bank Rakyat Indonesia sekitar 150 orang.

\section{Pendidikan Terakhir Nasabah}

Rendahnya tingkat pendidikan sangat berpengaruh 
pada jenis pekerjaan nasabah yaitu nelayan. Mereka lebih memilih bekerja sebagai nelayan karena kurangnya pengetahuan dalam bidang lain. yang akan dijadikan sebagai instrument pendukung dalam penelitian ini sebanyak 8 orang.

Faktor Faktor yang mendorong masyarakat nelayan di Kelurahan tanjung Kramat memilih dana kredit di Bank Rakyat Indonesia sebagai sumber pembiayaan

$\checkmark$ Faktor internal, yaitu faktor pendorong atau pertimbangan yang terkait dengan kegiatan melaut.

$\checkmark$ Fakor eksternal, yaitu faktor pendorong atau pertimbangan dari sisi penawaran dana yaitu sisi perbankan terdiri dari :

1. Cicilan yang murah

2. Nilai kredit

3. Jangka waktu kredit

4. Prosedur untuk peminjaman yang mudah.

Faktor-faktor yang menghambat masyarakat nelayan di Kelurahan Tanjung Kramat memilih dana kredit di Bank Rakyat Indonesia sebagai sumber pembiayaan

1. Cicilan kredit

2. Nilai Agunan

3. Jangka waktu kredit

4. Prosedur/persyaratan kredit
5. Lokasi (akses) bank penyedia kredit

Berdasarkan apa yang telah di deskripsikan pada paparan deskripsi hasil penelitian, maka pembahasan yang akan peneliti sajikan dimaksudkan untuk memberikan penjelasan makna dan mengemukakan temuan data yang telah diamati dan didalami: Efektivitas pemanfaaatan dana kredit bank BRI sebagai sumber pembiayaan bagi masyarakat nelayan di Kelurahan Tanjung Kramat.

Perhitungan efektifitas menggambarkan kemampuan nelayan dalam merealisasika pendapatan yang dibandingkan dengan rencana pendapatan berdasarkan potensi rill pendapatan. Semakin tinggi rasio efektifitas, menggambarkan kemampuan pemanfaatan dana Bank yang semakin baik. Oleh karena itu nelayan harus dapat mengatur dan meningkatkan penerimaan/pendapatan agar bisa menyesuaikan dengan pengeluaran kebutuhan sehingga kesejahteraan hidup masyarakat nelayan di Kelurahan Tanjung Kramat dapat terpenuhi dengan baik. 


\section{Kelengkapan peralatan alat produksi sebelum dan sesudah memanfaatkan dana Bank Rakyat Indonesia (BRI)}

Sebelum nasabah meminjam pada bank BRI ini, alat produksi (perlengkapan dan peralatan) yang digunakan nelayan untuk kegiatan melaut masih sangat tidak memadai. Hal ini dikarenakan kurangnya dana untuk membeli peralatan itu. Kelengkapan peralatan nelayan sebelum memanfaatkan dana Bank Rakyat Indonesia, rata rata ada nelayan yang tidak memiliki mesin tempel, jarring, dan nilon besar. Dan pada saat nelayan telah memanfaatkan atau meminjam dana Bank Rakyat Indonesia, semua nelayan sudah memiliki alat produksi yang lengkap.

Pendapatan nelayan sebelum dan sesudah memanfaatkan dana BRI

Kelengkapan alat produksi sangat berpengaruh pada pendapatan. Dengan alat produksi yang sangat memadai dapat meningkatkan pendapatan. Perubahan dari sbelum nelayan memanfaatkan dana Bank Rakyat Indonesia diperoleh data mayoritas pendapatan nelayan kurang lebih rata rata pendapatannya Rp. 500.000 sedangkan setelah memanfaatkan Bank Rakyat Indonesia sebagai pembiayaan untuk kelengkapan alat produksi pendapatan nelayan meningkat kurang lebih rata rata pendapatannya Rp. $\quad 1.000 .000$ (dengan menggunakan alat produksi yang lengkap).

\section{Tingkat Rasio efektifitas}

Adapun cara yang dilakukan untuk mengukur tingkat rasio efektifitas pembiayaan Bank Rakyat Indonesia yaitu sebagai berikut:

Rasio Efektifitas $=\frac{\text { Realisasi Pendapatan }}{\text { Rencana Pendapatan }} \times 100$

Berikut laporan tingkat rasio efektifitas untuk beberapa nelayan di Kelurahan Tanjung Kramat:

\begin{tabular}{|c|c|}
\hline Instrumen & Keterangan \\
\hline Instrumen 1 & Sangat Efektif \\
\hline Instrumen 2 & Sangat Efektif \\
\hline Instrumen 3 & Sangat Efektif \\
\hline Instrumen 4 & Sangat Efektif \\
\hline Instrumen 5 & Sangat Efektif \\
\hline Instrumen 6 & Sangat Efektif \\
\hline Instrumen 7 & Sangat Efektif \\
\hline Instrumen 8 & Sangat Efektif \\
\hline
\end{tabular}

Berdasarkan laporan diatas, terlihat bahwa pemanfaatan dana Bank Rakyat Indonesia sebagai sumber pembiayaaan terhadap pendapatan nelayan di Kelurahan Tanjung Kramat memiliki tingkat efektifitas di atas 100\%. Hasil ini 


\begin{abstract}
menunjukan bahwa dalam memanfaatkan dana Bank Rakyat Indonesia sangat efektif yang berarti dana Bank ini sangat membantu nelayan dalam memenuhi pembiayaan terutama untuk pembiayaan alat produksi yang sangat berpengaruh pada pendapatan.
\end{abstract}

Faktor-faktor yang mendorong masyarakat nelayan di Kelurahan Tanjung Kramat memilih dana kredit di Bank Rakyat Indonesia sebagai sumber pembiayaan

Berdasarkan temuan yang dipaparkan sebelumya dalam deskripsi hasil penelitian, maka terdapat faktor yang mendorong masyarakat nelayan di Kelurahan Tanjung Kramat memilih dana kredit di Bank Rakyat Indonesia sebagai sumber pembiayaan.

$\checkmark$ Faktor internal, yaitu faktor pendorong atau pertimbangan yang terkait dengan kegiatan melaut.

$\checkmark$ Faktor eksternal, yaitu faktor pendorong atau pertimbangan dari sisi penawaran dana yaitu sisi perbankan terdiri dari:

1. Cicilan yang murah

2. Penyaluran dana

3. Nilai kredit

4. Jangka waktu kredit
5. Prosedur untuk peminjaman yang mudah.

Faktor faktor yang menghambat masyarakat nelayan di Kelurahan Tanjung Kramat memilih dana kredit di Bank Rakyat Indonesia sebagai sumber pembiayaan

Berdasarkan temuan yang dipaparkan sebelumya dalam deskripsi hasil penelitian, maka terdapat factor yang menghambat masyarakat nelayan di Kelurahan Tanjung Kramat memilih dana kredit di Bank Rakyat Indonesia sebagai sumber pembiayaan:

1. Cicilan kredit

2. Nilai Agunan

3. Jangka waktu kredit

4. Prosedur/persyaratan kredit

5. Lokasi (akses) bank penyedia kredit

\section{Penutup \\ Simpulan}

1. Terdapat efektifitas dalam pemanfaatan dana Bank rakyat Indonesia ini. Dari hasil analisis yang dilakukan didapat tingkat rasio efektifitasnya lebih dari 100\%. Hal itu berarti dana Bank Rakyat Indonesia ini benarbenar dapat dimanfaatkan oleh Nelayan Kelurahan Tanjung Kramat dan sangat membantu untuk sumber pembiayaan 
terutama dalam pembiayaan alat produksi guna untuk meningkatkan pendapatan.

2. Faktor-faktor yang mendorong masyarakat nelayan di Kelurahan Tanjung Kramat memilih dana Bank rakyat Indonesia ini yaitu dipengaruhi oleh faktor internal dan faktor eksternal.

$\checkmark$ Faktor internal, yaitu faktor pendorong atau pertimbangan yang terkait dengan kegiatan melaut.

$\checkmark$ Fakor eksternal, yaitu faktor pendorong atau pertimbangan dari sisi penawaran dana yaitu sisi perbankan terdiri dari cicilan yang murah, nilai kredit, nilai agunan, jangka waktu kredit, dan prosedur untuk peminjaman yang mudah.

3. Faktor-faktor yang menghambat masyarakat nelayan di Kelurahan Tanjung Kramat memilih dana Bank rakyat Indonesia ini yaitu dipengaruhi oleh cicilan kredit, nilai kredit, nilai agunan, jangka waktu kredit, presedur/persyaratan kredit, alokasi penyedia kredit dan lainnya.

\section{Saran}

1) Bank Rakyat Indonesia sebagai lembaga keuangan ini diharapkan pinjaman tersebut dapat terus diberikan bagi nelayan khususnya yang betulbetul membutuhkan dana. Karena bila dilihat pada kondisi sekarang ini mencari pekerjaan sangat sulit, dalam bekerja pun kelengkapan peralatan sangat diperlukan guna meningkatkan pendapatan dan diharapkan tidak mengurangi segi keefektifitasannya dalam aplikasinya.

2) Bank Rakyat Indonesia diharapkan dapat terus dikembangkan dalam bentuk pinjaman dan dipermudah proses peminjaman dalam rangka membantu para nelayan.

3) Bagi penulis sendiri dan masyakat adalah memberikan pengetahuan tentang fungsi, kegunaan Bank Rakyat Indonesia serta efektifitasnya.

4) Diharapkan kepada pemerintah untuk memajukan kebijakan Bank Rakyat Indonesia agar para nelayan dapat terbantu khususnya dalam segi pembiayaan untuk alat produksi guna meningkatkan pendapatan. 


\section{DAFTAR PUSTAKA}

Antonio, M. Syafi'I, (2001), Bank Syariah, Dari Teori ke Prakter, Gema Insani, Jakarta

Arifin, Zainul, (2002), Memahami Bank Syariah, Lingkup Peluang, Tantangan Dan Prospek, Alvebat, Jakarta.

Bogdan (Dalam Sugiyono: 2017). Metode Penelitian Kualitatif. Alfabeta : Bandung.

Creswell. 2012 (Dalam Sugiyono: 2017). Metode Penelitian Kualitatif. Alfabeta : Bandung.

Darmadji, Tjipto dan Hendy M.F., (2001). Pasar Modal di Indonesia. Salemba Empat : Jakarta.

Intan, Raden, Peran Bank Syariah Dalam Pemberdayaan usaha Nelayan Di Pulau Pasaran. Skripsi. Fakultas ilmu ekonomi dan bisnis islam. 1439 H. Diakses pada tanggal 05 maret 2019

Kamus Besar Bahasa Indonesia (KBBI). 2013. Tentang Definisi Efektivitas

Kasmir, 2012. Bank dan Lembaga Keuangan Lainnya. Rajawali Pers Jakarta.

Miles dan Huberman. 1984 (Dalam Sugiyono: 2017). Analisis Data Model Miles dan Huberman. Alfabeta : Bandung.
Nasution. 1988 (Dalam Sugiyono: 2017). Metode Penelitian Kualitatif. Alfabeta : Bandung. Sugiyono. 2017. Metode Penelitian Kualitatif. Alfabeta : Bandung Susan Stainback. 1988 (Dalam Sugiyono: 2017). Metode Penelitian Kualitatif. Alfabeta Bandung. 